\title{
EFFECTS OF SUBLETHAL COPPER EXPOSURE ON NUCLEIC ACID LEVELS IN FISH, OREOCHROMIS MOSSAMBICUS (PETERS)
}

\author{
Jagadeshwarlu Rapaka and G. Sunitha Devi \\ Department of Zoology, University College of Science, Osmania University, \\ Hyderabad, Telangana- 500 007, India. \\ jagadeesh.rapaka@gmail.com
}

\begin{abstract}
Industries are the major sources of heavy metal pollution and it is released into water and soil. Heavy metals cause several ill effects to aquatic organisms and environment. In the present study, Fishes were exposed to sub lethal concentrations $\left(1 / 16,1 / 12,1 / 8\right.$ and $1 / 4^{\text {th }}$ of $96 \mathrm{~h} \mathrm{LC}_{50}$ value) i.e. $3 \mathrm{mg} / \mathrm{L}, 4 \mathrm{mg} / \mathrm{L}, 6 \mathrm{mg} / \mathrm{L}$ and $12 \mathrm{mg} / \mathrm{L}$ of Copper Sulphate for four different exposure durations of 10, 20, 30 and 40 days. The Nucleic acids (RNA and DNA) in different tissues such as Muscle, Liver, Gills and Kidney of Copper Sulphate (CuSO4) exposed fish, Oreochromis mossambicus has been studied. Decreased tendency was observed in RNA and an insignificant change was observed in DNA levels in all the vital tissues of fish exposed to Copper Sulphate over control. RNA content was gradually decreased with increased exposure period and the decrease was observed to be directly proportional to increased sublethal concentrations. DNA levels decreased higher concentration $(12 \mathrm{mg} / \mathrm{L})$ and higher duration (40 days).
\end{abstract}

KEYWORDS: Oreochromis mossambicus, Copper Sulphate, RNA and DNA.

\section{INTRODUCTION}

Water is an important natural resource essential for all living beings. The important water resources are ponds, lakes, rivers streams, etc. These water bodies provide water for drinking, irrigation, cooling industrial machines, and for other domestic purposes. So any harmful change in the water causes many ill-effects on the life of man and other animals ${ }^{1}$. The undesirable change in water that has harmful affect on the life of man and domestic plants and animals is called water pollution. Heavy metals are important environmental pollutants and their toxicity is a problem of increasing significance for ecological, evolutionary, nutritional and environmental reasons $^{2}$. Threatening effect of metals is a serious problem which is increasing at an alarming rate all over the world. Rapid industrialization and the usage of pesticides, rodenticides etc., containing metals and metalloids in the name of modern agriculture contaminated the environment ${ }^{3},{ }^{4}$. Environmental pollution due to heavy metals commonly arises during the smelting of ores and the preparation of nuclear fuels. An important property of heavy metals is that they are immutable and non-degradable in physical as well as biological systems. Heavy metal poisoning is believed to interfere with metabolic pathways in vital organs through different mechanisms in living organisms. It is believed that metals 
may exert their effects directly by interfering with endocrine system and/or they may alter many metabolic body processes ${ }^{5}$.

Copper sulphate is a fungicide used to control bacterial and fungal diseases of fruit vegetable, nuts and field crops like mildew, leaf spots, blights and apple scab. It is also used as an algaecide, an herbicide in irrigation and municipal water treatment system and for controlling phytoplankton in fish ponds and lakes as well as a herbicide used in aquatic weed control since $1982^{6}$. But if copper levels are not properly controlled, the element can be very harmful. Studies have shown the negative effects of various copper formulations on entomopathogenic fungi, nematodes, and parasitoids, and some have found that it is harmful to other organisms. ${ }^{7}$ Showed that copper has toxic effects on the larval development of the barnacle Balanus Amphitrite and that molting was a more sensitive end-point than survival.

Studies on different biochemical parameters have proved useful in determining the adaptive and protective mechanisms of the body to resist the toxic effects of the toxic substances. Any alteration in biochemical parameters can result in serious outcomes in the form of various diseases in both the fish and its consumer. The development and growth of the fishes depend upon the DNA and RNA which serve as biochemical indices ${ }^{8}$. Cellular enlargement and active protein synthesis are dependent on DNA and RNA content. The Nucleic Acids play decisive role in regulating cellular activities so that they serve as important biomarkers of metabolic potential of cells in organism ${ }^{9}$. Ribonucleic acid or RNA is a nucleic acid polymer consisting of nucleotide monomers that plays several important roles in the processes that translate genetic information from deoxyribonucleic acid (DNA) into protein products; RNA acts as a messenger between DNA and the protein synthesis complexes known as ribosomes, forms vital portions of ribosomes, and acts as an essential carrier molecule for amino acids to be used in protein synthesis. RNA is a polymer with a ribose and phosphate backbone and four different bases: adenine, guanine, cytosine, and uracil ${ }^{10}$.

Some RNA molecules play an active role within cells by catalyzing biological reactions, controlling gene expression, or sensing and communicating responses to cellular signals. One of these active processes is protein synthesis, a universal function where RNA molecules direct the assembly of proteins on ribosomes. This process uses transfer RNA (tRNA) molecules to deliver amino acids to the ribosome, where ribosomal RNA (rRNA) then links amino acids together to form proteins ${ }^{11}$.

Deoxyribonucleic acid (DNA) is a molecule that carries the genetic information used in the growth, development, functioning and reproduction of all living organisms. The two DNA strands are called polynucleotides since they are composed of simpler monomer units called 
nucleotides ${ }^{12},{ }^{13}$. Each nucleotide is composed of one of four nitrogen-containing nucleobases - Cytosine (C), Guanine (G), Adenine (A) or Thymine (T) - a sugar called deoxyribose and a phosphate group. The nucleotides are joined to one another in a chain by covalent bonds between the sugar of one nucleotide and the phosphate of the next, resulting in an alternating sugarphosphate backbone ${ }^{14}$. The nitrogenous bases of the two separate polynucleotide strands are bound together, according to base pairing rules (A with $\mathrm{T}$ and $\mathrm{C}$ with $\mathrm{G}$ ), with hydrogen bonds to make doublestranded DNA. The total amount of related DNA base pairs on Earth is estimated at 5.0 $\mathrm{x} 1037$ and weighs 50 billion tonnes. The nucleic acids play decisive role in regulating cellular activities so that they serve as important biomarkers of metabolic potential of cells in organism. The fall in nucleic acids content in the tissues of present experimental fishes is suggestive of impairment of protein synthesis?.

The purpose of present investigation was to determine the effect of copper sulphate on RNA and DNA levels of certain important tissues, i.e. Muscle, Liver, Gills and Kidney of fish, Oreochromis mossambicus.

\section{MATERIALS AND METHODS}

The fish, Oreochromis mossambicus weighing about $12 \pm 1$ gram used for present study. The fishes were collected from Telangana state fisheries center. They were transported to the laboratory in oxygenated containers and treated with $0.1 \% \mathrm{KMnO}_{4}$ to avoid dermal infection and acclimatized to laboratory conditions for 10 days. The fishes were fed with commercial feed once a day at a rate of $2 \%$ of body weight both before and during the experiment. Temperature was maintained at 27 to $28^{\circ} \mathrm{C}$ and water was changed by fresh water every day. Before to starting the experiment, $\mathrm{LC}_{50}$ value was calculated by Finney Probit analysis method ${ }^{15}$ and the $\mathrm{LC}_{50}$ was obtained as $48 \mathrm{mg} / \mathrm{L}$ at 96 hours exposure period. Nucleic acids (RNA and DNA) were estimated in four different tissues like muscle, liver, gills and kidneys by exposing the fishes to four sublethal concentrations of $\mathrm{CuSO}_{4}$ i.e. $12 \mathrm{mg} / \mathrm{L}\left(1 / 4^{\text {th }}\right.$ of $\left.\mathrm{LC}_{50}\right), 6$ $\mathrm{mg} / \mathrm{L}\left(1 / 8^{\text {th }}\right.$ of $\left.\mathrm{LC}_{50}\right), 4 \mathrm{mg} / \mathrm{L}\left(1 / 12^{\text {th }}\right.$ of $\left.\mathrm{LC}_{50}\right)$ and $3 \mathrm{mg} / \mathrm{L}\left(1 / 16^{\text {th }}\right.$ of $\left.\mathrm{LC}_{50}\right)$ for four different durations (10, 20, 30 and 40 days). Nucleic acids were extracted by ${ }^{16}$, RNA was estimated by Orcinol method and DNA was estimated by Diphenyl Amine method.

\section{RESULTS AND DISCUSSION}

After exposing the fish, Oreochromis mossambicus to different Sub lethal Concentration of Copper Sulphate $\left(\mathrm{CuSO}_{4}\right)$, $12 \mathrm{mg} / \mathrm{L}\left(1 / 4^{\text {th }}\right.$ of $\left.\mathrm{LC}_{50}\right), 6 \mathrm{mg} / \mathrm{L}\left(1 / 8^{\text {th }}\right.$ of $\left.\mathrm{LC}_{50}\right), 4 \mathrm{mg} / \mathrm{L}\left(1 / 12^{\text {th }}\right.$ of $\left.\mathrm{LC}_{50}\right)$, and $3 \mathrm{mg} /$ $\mathrm{L}\left(1 / 16^{\text {th }}\right.$ of $\left.\mathrm{LC}{ }_{50}\right)$ for four different durations $(10,20,30$ and 40 days) of exposure on Nucleic acids content in Muscle, Liver, Gills and kidneys of Oreochromis mossambicus fish were studied and the results were statically analyzed. The variations in levels of Nucleic acids in 
Table 1. RNA content in fish Muscle after exposure to sublethal concentrations of Copper compared to control

\begin{tabular}{|c|c|c|c|c|c|}
\hline \multirow{2}{*}{\multicolumn{2}{|c|}{$\mathrm{CuSO}_{4} \mathrm{mg} / \mathrm{L}$}} & \multicolumn{4}{|c|}{ Days of exposure } \\
\hline & & \multirow{2}{*}{$\frac{10 \text { days }}{3.070}$} & \multirow{2}{*}{$\frac{20 \text { days }}{3.060}$} & \multirow{2}{*}{$\begin{array}{c}30 \text { days } \\
3.080\end{array}$} & \multirow{2}{*}{$\begin{array}{c}40 \text { days } \\
3.070\end{array}$} \\
\hline Control & Mean & & & & \\
\hline & SE & \pm 0.039 & \pm 0.029 & \pm 0.121 & \pm 0.049 \\
\hline \multirow[t]{3}{*}{$3 \mathrm{mg} / \mathrm{L}$} & Mean & $3.087^{\mathrm{NS}}$ & $2.827^{\mathrm{NS}}$ & $2.407 *$ & $2.212 *$ \\
\hline & SE & \pm 0.018 & \pm 0.020 & \pm 0.032 & \pm 0.019 \\
\hline & $\% \mathrm{~V}$ & 0.54 & -7.62 & -21.86 & -27.96 \\
\hline \multirow[t]{3}{*}{$4 \mathrm{mg} / \mathrm{L}$} & Mean & $2.997^{\mathrm{NS}}$ & $2.727 *$ & $2.317 * *$ & $1.970 * *$ \\
\hline & SE & \pm 0.041 & \pm 0.029 & \pm 0.025 & \pm 0.023 \\
\hline & $\% \mathrm{~V}$ & -2.39 & -10.89 & -24.78 & -35.82 \\
\hline \multirow[t]{3}{*}{$6 \mathrm{mg} / \mathrm{L}$} & Mean & $3.007^{\mathrm{NS}}$ & $2.613^{*}$ & $2.212 * *$ & $1.720 * * *$ \\
\hline & SE & \pm 0.03 & \pm 0.02 & \pm 0.025 & \pm 0.021 \\
\hline & $\% \mathrm{~V}$ & -2.06 & -14.59 & -28.19 & -43.97 \\
\hline \multirow[t]{3}{*}{$12 \mathrm{mg} / \mathrm{L}$} & Mean & $2.873 *$ & $2.223 * *$ & $1.723 * * *$ & $1.433 * * *$ \\
\hline & SE & \pm 0.02 & \pm 0.018 & \pm 0.026 & \pm 0.026 \\
\hline & $\% \mathrm{~V}$ & -6.40 & -27.34 & -44.04 & -53.31 \\
\hline
\end{tabular}

Table 2. RNA content in fish Liver after exposure to sublethal concentrations of Copper compared to control

\begin{tabular}{|c|c|c|c|c|c|}
\hline \multirow{2}{*}{\multicolumn{2}{|c|}{$\mathrm{CuSO}_{4} \mathrm{mg} / \mathrm{L}$}} & \multicolumn{4}{|c|}{ Days of exposure } \\
\hline & & \multirow{2}{*}{$\frac{10 \text { days }}{4.390}$} & \multirow{2}{*}{$\begin{array}{c}20 \text { days } \\
4.400\end{array}$} & \multirow{2}{*}{$\begin{array}{c}\text { 30 days } \\
4.370\end{array}$} & \multirow{2}{*}{$\begin{array}{c}40 \text { days } \\
4.380\end{array}$} \\
\hline Control & Mean & & & & \\
\hline & SE & \pm 0.021 & \pm 0.023 & \pm 0.02 & \pm 0.02 \\
\hline \multirow[t]{3}{*}{$3 \mathrm{mg} / \mathrm{L}$} & Mean & $4.117^{\mathrm{NS}}$ & $4.013^{\mathrm{NS}}$ & $3.870 *$ & $3.677 *$ \\
\hline & SE & \pm 0.02 & \pm 0.055 & \pm 0.063 & \pm 0.061 \\
\hline & $\% \mathrm{~V}$ & -6.22 & -8.78 & -11.43 & -16.05 \\
\hline \multirow[t]{3}{*}{$4 \mathrm{mg} / \mathrm{L}$} & Mean & $4.071^{\mathrm{NS}}$ & $3.803 *$ & $3.640 *$ & $3.231 * *$ \\
\hline & SE & \pm 0.011 & \pm 0.072 & \pm 0.018 & \pm 0.023 \\
\hline & $\% \mathrm{~V}$ & -7.27 & -13.56 & -16.69 & -26.23 \\
\hline \multirow[t]{3}{*}{$6 \mathrm{mg} / \mathrm{L}$} & Mean & $4.007^{\mathrm{NS}}$ & $3.727 *$ & $3.087 * *$ & $2.830 * * *$ \\
\hline & SE & \pm 0.047 & \pm 0.173 & \pm 0.012 & \pm 0.023 \\
\hline & $\% \mathrm{~V}$ & -8.73 & -15.30 & -29.36 & -35.38 \\
\hline \multirow[t]{3}{*}{$12 \mathrm{mg} / \mathrm{L}$} & Mean & $3.817 *$ & $3.450 * *$ & $2.850 * * *$ & $2.367 * * *$ \\
\hline & SE & \pm 0.061 & \pm 0.07 & \pm 0.055 & \pm 0.061 \\
\hline & $\% \mathrm{~V}$ & -13.06 & -21.58 & -34.77 & -45.96 \\
\hline
\end{tabular}

121 • J. Adv. Zool. $2021: 42(1)$ 
Table 3. RNA content in fish Gill after exposure to sublethal concentrations of Copper compared to control

\begin{tabular}{|c|c|c|c|c|c|}
\hline \multirow{2}{*}{\multicolumn{2}{|c|}{$\mathrm{CuSO}_{4} \mathrm{mg} / \mathrm{L}$}} & \multicolumn{4}{|c|}{ Days of exposure } \\
\hline & & \multirow{2}{*}{$\begin{array}{c}10 \text { days } \\
2.850\end{array}$} & \multirow{2}{*}{$\begin{array}{c}20 \text { days } \\
2.860\end{array}$} & \multirow{2}{*}{\begin{tabular}{|c|}
30 days \\
2.870
\end{tabular}} & \multirow{2}{*}{$\begin{array}{c}40 \text { days } \\
2.840\end{array}$} \\
\hline Control & Mean & & & & \\
\hline & SE & \pm 0.023 & \pm 0.02 & \pm 0.01 & \pm 0.009 \\
\hline \multirow[t]{3}{*}{$3 \mathrm{mg} / \mathrm{L}$} & Mean & $2.8133^{\mathrm{NS}}$ & $2.7503^{\mathrm{NS}}$ & $2.6767^{\mathrm{NS}}$ & $2.6567^{\mathrm{NS}}$ \\
\hline & SE & \pm 0.026 & \pm 0.023 & \pm 0.009 & \pm 0.012 \\
\hline & $\% \mathrm{~V}$ & -1.29 & -3.83 & -6.73 & -6.45 \\
\hline \multirow[t]{3}{*}{$4 \mathrm{mg} / \mathrm{L}$} & Mean & $2.703^{\mathrm{NS}}$ & $2.561 *$ & $2.457 *$ & $2.373 * *$ \\
\hline & SE & \pm 0.03 & \pm 0.016 & \pm 0.023 & \pm 0.035 \\
\hline & $\% \mathrm{~V}$ & -5.15 & -10.44 & -14.40 & -16.43 \\
\hline \multirow[t]{3}{*}{$6 \mathrm{mg} / \mathrm{L}$} & Mean & $2.687^{\mathrm{NS}}$ & $2.507 * *$ & $2.317 * *$ & $2.187 * * *$ \\
\hline & $\mathrm{SE}$ & \pm 0.018 & \pm 0.015 & \pm 0.032 & \pm 0.02 \\
\hline & $\% \mathrm{~V}$ & -5.74 & -12.35 & -19.28 & -23.00 \\
\hline \multirow[t]{3}{*}{$12 \mathrm{mg} / \mathrm{L}$} & Mean & $2.677 *$ & $2.227 * *$ & $2.027 * * *$ & $1.870^{* * *}$ \\
\hline & SE & \pm 0.026 & \pm 0.02 & \pm 0.012 & \pm 0.012 \\
\hline & $\% \mathrm{~V}$ & -6.09 & -22.14 & -29.38 & -34.15 \\
\hline
\end{tabular}

Table 4. RNA content in fish Kidney after exposure to sublethal concentrations of Copper compared to control

\begin{tabular}{|c|c|c|c|c|c|}
\hline \multirow{2}{*}{\multicolumn{2}{|c|}{$\mathrm{CuSO}_{4} \mathrm{mg} / \mathrm{L}$}} & \multicolumn{4}{|c|}{ Days of exposure } \\
\hline & & \multirow{2}{*}{$\frac{10 \text { days }}{4.240}$} & \multirow{2}{*}{$\begin{array}{c}20 \text { days } \\
4.250\end{array}$} & \multirow{2}{*}{$\begin{array}{c}30 \text { days } \\
4.230\end{array}$} & \multirow{2}{*}{$\frac{40 \text { days }}{4.240}$} \\
\hline Control & Mean & & & & \\
\hline & SE & \pm 0.015 & \pm 0.015 & \pm 0.020 & \pm 0.012 \\
\hline \multirow[t]{3}{*}{$3 \mathrm{mg} / \mathrm{L}$} & Mean & $4.053^{\mathrm{NS}}$ & $3.871^{\mathrm{NS}}$ & $3.633 *$ & $3.517 *$ \\
\hline & SE & \pm 0.049 & \pm 0.017 & \pm 0.015 & \pm 0.020 \\
\hline & $\% \mathrm{~V}$ & -4.40 & -8.92 & -14.10 & -17.06 \\
\hline \multirow[t]{3}{*}{$4 \mathrm{mg} / \mathrm{L}$} & Mean & $4.05^{\mathrm{NS}}$ & $3.810 *$ & $3.577 *$ & $3.450 * *$ \\
\hline & SE & \pm 0.023 & \pm 0.035 & \pm 0.032 & \pm 0.017 \\
\hline & $\% \mathrm{~V}$ & -4.46 & -10.34 & -15.44 & -18.62 \\
\hline \multirow[t]{3}{*}{$6 \mathrm{mg} / \mathrm{L}$} & Mean & $4.033^{\mathrm{NS}}$ & $3.740 * *$ & $3.447 * *$ & $3.243 * * *$ \\
\hline & SE & \pm 0.015 & \pm 0.018 & \pm 0.020 & \pm 0.018 \\
\hline & $\% \mathrm{~V}$ & -4.87 & -11.99 & -18.52 & -23.50 \\
\hline \multirow[t]{3}{*}{$12 \mathrm{mg} / \mathrm{L}$} & Mean & $3.913 *$ & $3.643 * *$ & $3.250 * * *$ & $2.827 * * *$ \\
\hline & SE & \pm 0.023 & \pm 0.015 & \pm 0.023 & \pm 0.009 \\
\hline & $\% \mathrm{~V}$ & -7.70 & -14.27 & -23.16 & -33.33 \\
\hline
\end{tabular}

122 • J. Adv. Zool. $2021: 42(1)$ 
Table 5. DNA content in fish Muscle after exposure to sublethal concentrations of Copper compared to control

\begin{tabular}{|c|c|c|c|c|c|}
\hline \multirow{2}{*}{\multicolumn{2}{|c|}{$\mathrm{CuSO}_{4} \mathrm{mg} / \mathrm{L}$}} & \multicolumn{4}{|c|}{ Days of exposure } \\
\hline & & \multirow{2}{*}{$\begin{array}{c}10 \text { days } \\
2.080\end{array}$} & \multirow{2}{*}{$\begin{array}{c}20 \text { days } \\
2.060\end{array}$} & \multirow{2}{*}{$\begin{array}{c}30 \text { days } \\
2.050\end{array}$} & \multirow{2}{*}{$\begin{array}{c}40 \text { days } \\
2.060\end{array}$} \\
\hline Control & Mean & & & & \\
\hline & SE & \pm 0.007 & \pm 0.005 & \pm 0.008 & \pm 0.008 \\
\hline \multirow[t]{2}{*}{$3 \mathrm{mg} / \mathrm{L}$} & Mean & $2.070^{\mathrm{NS}}$ & $2.050^{\mathrm{NS}}$ & $2.040^{\mathrm{NS}}$ & $2.031^{\mathrm{NS}}$ \\
\hline & SE & \pm 0.004 & \pm 0.005 & \pm 0.006 & \pm 0.009 \\
\hline \multirow[t]{2}{*}{$4 \mathrm{mg} / \mathrm{L}$} & Mean & $2.060^{\mathrm{NS}}$ & $2.040^{\mathrm{NS}}$ & $2.031^{\mathrm{NS}}$ & $1.950^{\mathrm{NS}}$ \\
\hline & SE & \pm 0.018 & \pm 0.023 & \pm 0.029 & \pm 0.003 \\
\hline \multirow[t]{2}{*}{$6 \mathrm{mg} / \mathrm{L}$} & Mean & $2.050^{\mathrm{NS}}$ & $2.011^{\mathrm{NS}}$ & $1.980^{\mathrm{NS}}$ & $1.867 *$ \\
\hline & $\mathrm{SE}$ & \pm 0.012 & \pm 0.029 & \pm 0.023 & \pm 0.003 \\
\hline \multirow[t]{2}{*}{$12 \mathrm{mg} / \mathrm{L}$} & Mean & $2.010^{\mathrm{NS}}$ & $1.923 *$ & $1.863 *$ & $1.810 * *$ \\
\hline & SE & \pm 0.009 & \pm 0.015 & \pm 0.009 & \pm 0.009 \\
\hline
\end{tabular}

Each value is the Mean \pm SE of six individual observations

Values are expressed as mg of DNA/ gram wet weight of tissue

SE - Standard Error.

NS : Not Significant, $* \mathrm{P}<0.05, * * \mathrm{P}<0.01$

Table 5. DNA content in fish Muscle after exposure to sublethal concentrations of Copper compared to control

\begin{tabular}{|c|c|c|c|c|c|}
\hline \multirow{2}{*}{\multicolumn{2}{|c|}{$\mathrm{CuSO}_{4} \mathrm{mg} / \mathrm{L}$}} & \multicolumn{4}{|c|}{ Days of exposure } \\
\hline & & \multirow{2}{*}{$\frac{10 \text { days }}{1.680}$} & \multirow{2}{*}{$\begin{array}{c}20 \text { days } \\
1.670\end{array}$} & \multirow{2}{*}{$\begin{array}{c}30 \text { days } \\
1.670\end{array}$} & \multirow{2}{*}{$\begin{array}{c}\mathbf{4 0} \text { days } \\
1.710\end{array}$} \\
\hline Control & Mean & & & & \\
\hline & SE & \pm 0.023 & \pm 0.026 & \pm 0.032 & \pm 0.009 \\
\hline \multirow[t]{2}{*}{$3 \mathrm{mg} / \mathrm{L}$} & Mean & $1.711^{\mathrm{NS}}$ & $1.687^{\mathrm{NS}}$ & $1.650^{\mathrm{NS}}$ & $1.613^{\mathrm{NS}}$ \\
\hline & SE & \pm 0.018 & \pm 0.020 & \pm 0.015 & \pm 0.038 \\
\hline \multirow[t]{2}{*}{$4 \mathrm{mg} / \mathrm{L}$} & Mean & $1.687^{\mathrm{NS}}$ & $1.647^{\mathrm{NS}}$ & $1.614^{\mathrm{NS}}$ & $1.593^{\mathrm{NS}}$ \\
\hline & SE & \pm 0.009 & \pm 0.020 & \pm 0.018 & \pm 0.015 \\
\hline \multirow[t]{2}{*}{$6 \mathrm{mg} / \mathrm{L}$} & Mean & $1.640^{\mathrm{NS}}$ & $1.613^{\mathrm{NS}}$ & $1.583^{\mathrm{NS}}$ & $1.547 *$ \\
\hline & SE & \pm 0.018 & \pm 0.012 & \pm 0.015 & \pm 0.02 \\
\hline \multirow[t]{2}{*}{$12 \mathrm{mg} / \mathrm{L}$} & Mean & $1.640^{\mathrm{NS}}$ & $1.603 *$ & $1.567 *$ & $1.527 * *$ \\
\hline & SE & \pm 0.018 & \pm 0.023 & \pm 0.021 & \pm 0.020 \\
\hline
\end{tabular}

Each value is the Mean $\pm \mathrm{SE}$ of six individual observations

Values are expressed as mg of DNA/ gram wet weight of tissue

NS : Not Significant, $* \mathrm{P}<0.05, * * \mathrm{P}<0.01$

SE - Standard Error. 
Table 7. DNA content in fish Gill after exposure to sublethal concentrations of Copper compared to control

\begin{tabular}{|c|c|c|c|c|c|}
\hline \multirow{2}{*}{\multicolumn{2}{|c|}{$\mathrm{CuSO}_{4} \mathrm{mg} / \mathrm{L}$}} & \multicolumn{4}{|c|}{ Days of exposure } \\
\hline & & \multirow{2}{*}{$\begin{array}{c}10 \text { days } \\
2.571\end{array}$} & \multirow{2}{*}{$\begin{array}{c}20 \text { days } \\
2.560\end{array}$} & \multirow{2}{*}{$\begin{array}{c}30 \text { days } \\
2.547\end{array}$} & \multirow{2}{*}{$\begin{array}{c}40 \text { days } \\
2.565\end{array}$} \\
\hline Control & Mean & & & & \\
\hline & SE & \pm 0.037 & \pm 0.029 & \pm 0.018 & \pm 0.026 \\
\hline \multirow[t]{2}{*}{$3 \mathrm{mg} / \mathrm{L}$} & Mean & $2.500^{\mathrm{NS}}$ & $2.450^{\mathrm{NS}}$ & $2.441^{\mathrm{NS}}$ & $2.380^{\mathrm{NS}}$ \\
\hline & SE & \pm 0.018 & \pm 0.015 & \pm 0.043 & \pm 0.015 \\
\hline \multirow[t]{2}{*}{$4 \mathrm{mg} / \mathrm{L}$} & Mean & $2.460^{\mathrm{NS}}$ & $2.400^{\mathrm{NS}}$ & $2.360^{\mathrm{NS}}$ & $2.320^{\mathrm{NS}}$ \\
\hline & SE & \pm 0.015 & \pm 0.018 & \pm 0.019 & \pm 0.007 \\
\hline \multirow[t]{2}{*}{$6 \mathrm{mg} / \mathrm{L}$} & Mean & $2.430^{\mathrm{NS}}$ & $2.360^{\mathrm{NS}}$ & $2.310^{\mathrm{NS}}$ & $2.280 *$ \\
\hline & $\mathrm{SE}$ & \pm 0.024 & \pm 0.009 & \pm 0.023 & \pm 0.105 \\
\hline \multirow[t]{2}{*}{$12 \mathrm{mg} / \mathrm{L}$} & Mean & $2.350^{\mathrm{NS}}$ & $2.270^{\mathrm{NS}}$ & $2.170 *$ & $2.050 * *$ \\
\hline & SE & \pm 0.012 & \pm 0.040 & \pm 0.017 & \pm 0.026 \\
\hline
\end{tabular}

Each value is the Mean \pm SE of six individual observations

Values are expressed as mg of DNA/ gram wet weight of tissue

SE - Standard Error.

NS : Not Significant, $* \mathrm{P}<0.05, * * \mathrm{P}<0.01$

Table 8. DNA content in fish Kidney after exposure to sublethal concentrations of Copper compared to control

\begin{tabular}{|l|c|c|c|c|c|}
\hline \multicolumn{2}{|c|}{ CuSO $_{4}$ mg/ L } & \multicolumn{4}{c|}{ Days of exposure } \\
\cline { 3 - 6 } & Mean & 10 days & 20 days & 30 days & 40 days \\
\hline \multirow{3}{*}{ Control } & 2.220 & 2.230 & 2.240 & 2.230 \\
\cline { 2 - 6 } & SE & \pm 0.012 & \pm 0.046 & \pm 0.041 & \pm 0.037 \\
\hline \multirow{3}{*}{$3 \mathrm{mg} / \mathrm{L}$} & Mean & $2.130^{\mathrm{NS}}$ & $2.150^{\mathrm{NS}}$ & $2.100^{\mathrm{NS}}$ & $2.070^{\mathrm{NS}}$ \\
\cline { 2 - 6 } & SE & \pm 0.009 & \pm 0.015 & \pm 0.009 & \pm 0.015 \\
\hline \multirow{3}{*}{$4 \mathrm{mg} / \mathrm{L}$} & Mean & $2.160^{\mathrm{NS}}$ & $2.100^{\mathrm{NS}}$ & $2.060^{\mathrm{NS}}$ & $2.010^{\mathrm{NS}}$ \\
\cline { 2 - 6 } & SE & \pm 0.032 & \pm 0.038 & \pm 0.032 & \pm 0.029 \\
\hline $6 \mathrm{mg} / \mathrm{L}$ & Mean & $2.110^{\mathrm{NS}}$ & $2.050^{\mathrm{NS}}$ & $2.000^{\mathrm{NS}}$ & $1.960^{\mathrm{NS}}$ \\
\cline { 2 - 6 } & SE & \pm 0.018 & \pm 0.011 & \pm 0.009 & \pm 0.020 \\
\hline $12 \mathrm{mg} / \mathrm{L}$ & Mean & $2.090^{\mathrm{NS}}$ & $2.010^{\mathrm{NS}}$ & $1.970^{*}$ & $1.910^{* *}$ \\
\cline { 2 - 6 } & SE & \pm 0.015 & \pm 0.015 & \pm 0.018 & \pm 0.012 \\
\hline
\end{tabular}

Each value is the Mean $\pm \mathrm{SE}$ of six individual observations

Values are expressed as mg of DNA/ gram wet weight of tissue

NS : Not Significant, $* \mathrm{P}<0.05, * * \mathrm{P}<0.01$

SE - Standard Error. 
different tissues given in figures (Table 1 to 8 and Figure 1 to 8 ) in terms of mean with Standard Error values over control. Nucleic acids constituents in $\mathrm{CuSO}_{4}$ exposed fish decreased significantly when compared with control.

In the present investigation, the Nucleic acid levels (RNA) in different tissues like muscle, Liver, Gills and Kidneys were observed under sublethal exposure of $\mathrm{CuSO}_{4}$. There was a significant decrease in RNA levels in all tissues at all durations and in all sublethal concentrations were observed. The order of decrease in different tissues when exposed to sublethal concentrations was observed as Muscle (61.19\%, $\mathrm{p}<0.001)>$ Liver $(49.79 \%, \mathrm{p}<$ $0.001)>$ Gills $(39.22 \%, \mathrm{p}<0.001)>$ Kidney $(36.14 \%, \mathrm{p}<0.001)$ of fish compared to control. Decrease of RNA amount was more at higher concentration of $\mathrm{CuSO}_{4}(12 \mathrm{mg} / \mathrm{L})$ and higher duration (40days). Similar results were observed by ${ }^{17}$ reported that the RNA content of male fish tissues gets reduced under Copper Sulphate $\left(\mathrm{CuSO}_{4}\right)$ exposure in the freshwater fish, Notopterus notopterus indicating Copper Sulphate $\left(\mathrm{CuSO}_{4}\right)$ as a pollutant effects the reduction in the nucleic acid content in the tissues. ${ }^{18}$ Studied that a short term exposure to Copper Sulphate, the RNA content of tissues get reduced in the freshwater fish, Clarias batrachus indicating Copper sulphate as pollutant effect to the nucleic acid content in the tissues.

A fall in RNA content in the tissues of Cyprinus carpio would reflects the inhibited synthesis of nucleic acids. This clearly evidences that the protein synthesis machinery of the fishes has been adversely affected. As per the version of 9 the quantitative changes in DNA and RNA levels in Cyprinus carpio would be due to increased activity of DNA and the inhibition of RNA polymerase function. ${ }^{19}$ study revealed that when the freshwater fish, Channa striata exposed to sublethal concentration of cypermethrin showed significant decreased in the level of RNA. While the RNA/ DNA ratio significantly changed at different exposure periods as compared to control group.

\section{CONCLUSION}

The present study indicates that $\mathrm{CuSO}_{4}$ caused alterations in biochemical parameters of Oerochromis mossambicus might be caused by intoxication of heavy metal. It is concluded that the utilization of Copper sulphate should be minimize and should create awareness among the people about the toxicity of Copper Sulphate on animals as well as on human. Since majority of heavy metals are released cumulatively and regularly, through the industrial and human activities their residues are known to bioaccumulate in the tissues of fish and other animals, and transfer via food chain to the human bodies, they grave risk to the health of the people who consume these fish seems to be considerable. The need to protect the people from undue exposure to the heavy metals through the food chain cannot be over emphasized. 


\section{REFERENCES}

1. Loucks, D.P. \& E. Van Beek, 2017. Water Resources Planning and Management: An Overview. In: Water Resource Systems Planning and Management. Springer, Cham. https://doi.org/10.1007/978-3-319-44234-1_1

2. Jaishankar, M., T. Tseten, N. Anbalagan, B.B. Mathew \& K.N. Beeregowda, 2014. Toxicity, mechanism and health effects of some heavy metals. Interdiscip Toxicol., 7(2):60-72.

3. Moulis, J.M., 2010. Cellular mechanisms of cadmium toxicity related to the homeostasis of essential metals. Biometals, 23(5), .877896.

4. Wu, A. \& Z. Zeng, 2012. Dynamic behaviors of memristor-based recurrent neural networks with time-varying delays. Neural Networks, $36,1-10$.

5. Tchounwou, P.B., C.G. Yedjou, A.K Patlolla \& D.J. Sutton, 2012. Heavy metal toxicity and the environment. In Molecular, clinical and environmental toxicology, pp. 133-164.

6. Carbonell, G. \& J.V. Tarazona, 2004. A proposed method to diagnose acute copper poisoning in cultured rainbow trout (Oncorhynchus mykiss). Sci. Total Environ., 2: 1329-1334.

7. Qiu, J.W., V. Thiyagarajan, S. Cheung \& P.Y. Qian, 2005. Toxic effects of copper on larval development of the barnacle Balanus amphitrite. Mar Pollut Bull., 51(8-12):68893.

8. Buckley, L.J., 1980. Changes in ribonucleic acid, deoxy ribonucleic acid and protein content during ontogenesis in winter flounder (Seudopleuronectes americanus) and the effect of starvation. Fisher. Bull., U.S., 77: 703-708.

9. Bhanu, A.P., 2016. Fate of Nucleic Acids in the Tissues of Cyprinis carpio under the Toxicity of Heavy Metals. International Journal of Pure and Applied Bioscience, 4(3), 197-200.
10. Sehra, S.S. \& S.K. Sehra, 2012. Conceptual Translation as a part of Gene Expression. International Journal of Computers \& Technology, 3(3b), 503-505.

11. Uday Bhaskar, Adeesh Nagpal, Himanshu Paul \& M. Yamuna, 2014. Genetic Code as Binary BCD and Gray Code, Research Journal of Pharmaceutical, Biological and Chemical Sciences, 5(1): 438-451.

12. Alberts, B., D. Bray, K. Hopkins, A. Johnson, J. Lewis, M. Raff, K. Roberts \& P. Walter, 2014. Energy generation in mitochondria and chloroplasts. Essential Cell Biology: An Introduction to the Molecular Biology of the Cell .407-445.

13. Lodish, H., 2008. Molecular cell biology. Macmillan.

14. Rozikov, U.A., 2016. Tree-hierarchy of DNA and distribution of holiday junctions, condmat. stat-mech, Cornell University Library.

15. Finney, D.J., 1971. Probit Analysis, (3rd edn). Cambridge University Press, Cambridge.

16. Munro, H.N. \& A. Fleck, 1966. Recent developments in the measurement of nucleic acids in biological materials. A supplementary review. Analyst, 91(1079), 78-88.

17. Ravikiran, K. \& R.S. Kulkarni, 2015. Nucleic acid content in male fresh water fish Notopterus notopterus exposed to copper sulphate. International Letters of Natural Sciences, 6: 1-8.

18. Kumar, Muneesh, Parvinder Kumar \& Sangeeta Devi, 2015. To study the DNA and RNA content in some tissues of freshwater fish Clarias batrachus exposed to heavy metal copper sulphate. Research Journal of Chemical and Environmental Sciences, 3(7): 17-21.

19. Raksheskar, G.A., 2012. Influence of cypermethrin on DNA, RNA and RNA/DNA ratio in gills of the freshwater fish Channa striata. Bioscience Discovery, 3(1): 17-19. 
Figure.1. RNA content in fish Muscle after exposure to sublethal concentrations of Copper compared to control ( Mean \pm SE)

Figure.2. RNA content in fish Liver after exposure to sublethal concentrations of Copper compared to control ( Mean \pm SE)

Figure.3. RNA content in Gill after exposure to sublethal concentrations of Copper compared to control ( Mean $\pm \mathrm{SE}$ )

Figure.4. RNA content in fish Kidney after exposure to sublethal concentrations of Copper compared to control ( Mean \pm SE) 
